\title{
Methylocapsa acidiphila gen. nov., sp. nov., a novel methane-oxidizing and dinitrogen-fixing acidophilic bacterium from Sphagnum bog
}

\footnotetext{
1 Institute of Microbiology, Russian Academy of Sciences, Moscow 117811, Russia

2 Institute of Biochemistry and Physiology of Microorganisms, Russian Academy of Sciences, Pushchino, Moscow region, 142292, Russia

3 Department of Civil and Environmental Engineering, The University of Michigan, Ann Arbor, MI 48109-2125, USA

${ }^{4}$ Max-Planck-Institut für Terrestrische Mikrobiologie, D-35043 Marburg, Germany

5 Center for Microbial Ecology, Michigan State University, East Lansing, MI 48824-1325, USA
}

\author{
Svetlana N. Dedysh, ${ }^{1,4}$ Valentina N. Khmelenina, ${ }^{2}$ Natalia E. Suzina, ${ }^{2}$ \\ Yuri A. Trotsenko, ${ }^{2}$ Jeremy D. Semrau, ${ }^{3}$ Werner Liesack $^{4}$ \\ and James M. Tiedje ${ }^{5}$
}

Author for correspondence: Svetlana N. Dedysh. Tel: +795 135 0591. Fax: +7951356530. e-mail:vdhome@bolshe.msk.ru

\begin{abstract}
A novel genus and species, Methylocapsa acidiphila gen. nov., sp. nov., are proposed for a methane-oxidizing bacterium isolated from an acidic Sphagnum peat bog. This bacterium, designated strain $\mathrm{B2}^{\top}$, represents aerobic, Gramnegative, colourless, non-motile, curved coccoids that form conglomerates covered by an extracellular polysaccharide matrix. The cells use methane and methanol as sole sources of carbon and energy and utilize the serine pathway for carbon assimilation. Strain $\mathrm{B2}^{\mathrm{T}}$ is a moderately acidophilic organism with growth between $\mathrm{pH} 4.2$ and 7.2 and at temperatures from 10 to $30^{\circ} \mathrm{C}$. The cells possess a well-developed system of intracytoplasmic membranes (ICM) packed in parallel on only one side of the cell membrane. This type of ICM structure represents a novel arrangement, which was termed type III. The resting cells are Azotobacter-type cysts. Strain $\mathrm{B2}^{\mathrm{T}}$ is capable of atmospheric nitrogen fixation; it possesses particulate methane monooxygenase and does not express soluble methane monooxygenase. The major phospholipid fatty acid is $18: 1 \omega 7 \mathrm{c}$ and the major phospholipids are phosphatidylglycerols. The $\mathrm{G}+\mathrm{C}$ content of the DNA is $63.1 \mathrm{~mol} \%$. This bacterium belongs to the $\alpha$-subclass of the Proteobacteria and is most closely related to the acidophilic methanotroph Methylocella palustris $K^{\top}$ (97.3\% 165 rDNA sequence similarity). However, the DNA-DNA hybridization value between strain $\mathrm{B2}^{\top}$ and Methylocella palustris $\mathrm{K}^{\top}$ is only $7 \%$. Thus, strain $\mathrm{B2}^{\top}$ is proposed to comprise a novel genus and species, Methylocapsa acidiphila gen. nov., sp. nov. Strain B2 ${ }^{\top}$ ( $=$ DSM $13967^{\top}=$ NCIMB $^{2}$ $13765^{\top}$ ) is the type strain.
\end{abstract}

Keywords: Methylocapsa acidiphila gen. nov., sp. nov., acidophilic methaneoxidizing bacterium, serine-pathway methanotrophs

\section{INTRODUCTION}

Recently, the use of acidic media with a low salt content enabled the enrichment of acidophilic methanotrophic communities from Sphagnum peat bogs of four boreal sites in West Siberia and European North Russia (Dedysh et al., 1998a). Three of the four enriched communities were obtained on nitrogen-

Abbreviations: ICM, intracytoplasmic membrane; $M O B$, methane-oxidizing bacterium; PHB, poly- $\beta$-hydroxybutyrate; $\mathrm{pMMO}$, particulate methane monooxygenase; sMMO, soluble methane monooxygenase.

The GenBank/EMBL/DDBJ accession number for the $16 \mathrm{~S}$ rRNA gene sequence of Methylocapsa acidiphila strain $\mathrm{B}^{\top}{ }^{\top}$ is AJ278726. sufficient media and three pure cultures of methaneoxidizing bacteria (MOB) were isolated from these enrichments (Dedysh et al., 1998b). These isolates, strains $\mathrm{K}^{\mathrm{T}}$, S6 and M131, were subsequently described as the first representatives of a novel genus of serinepathway methanotrophs within the $\alpha$-subclass of the Proteobacteria, namely Methylocella palustris (Dedysh et al., 2000). These moderately acidophilic MOB grow only on media with a low salt content (below $1 \mathrm{~g} \mathrm{l}^{-1}$ ) and the $\mathrm{pH}$ optimum for growth is $5 \cdot 0-5 \cdot 5$. Cells of Methylocella lack the intracytoplasmic membrane (ICM) structures that are highly characteristic for other methanotrophs, but contain a vesicular membrane system connected to the cytoplasmic membrane. In contrast to all other MOB that form phylogeneti- 
cally coherent clusters within the $\alpha$ - and $\gamma$-subclasses of the Proteobacteria, Methylocella is closely affiliated to the heterotrophic bacterium Beijerinckia indica subsp. indica. Methylocella palustris $\mathrm{K}^{\mathrm{T}}$ was the first and so far the only methanotrophic species for which the presence of genes encoding particulate methane monooxygenase (pMMO) could not be demonstrated based on a PCR assay considered universal for $p m o A$ genes encoding the active-site polypeptide of pMMO. These bacteria possess soluble MMO (sMMO) and the nucleotide sequence of the PCR-amplified fragment of $m m o X$, which encodes the $\alpha$-subunit of the sMMO hydroxylase, was identical to the sequence of $m m o X$ clones obtained from all three communities enriched on media supplemented with nitrate (Dedysh et al., 1998a).

The fourth acidophilic methanotrophic enrichment was obtained on nitrogen-free medium from Bakchar bog in West Siberia. In contrast to enrichments from samples of the other sites, no PCR products were obtained with $m m o X$-targeted primers and template DNA from this methanotrophic community. We also failed to isolate any MOB from this enrichment using the procedure developed for the isolation of Methylocella palustris $\mathrm{K}^{\mathrm{T}}$. In this paper, we report the isolation of a pure culture of an acidophilic methanotrophic bacterium from this enrichment using another isolation strategy. This novel methanotrophic isolate, designated strain $\mathrm{B} 2^{\mathrm{T}}$, represents a genotype and phenotype clearly different from Methylocella palustris $\mathrm{K}^{\mathrm{T}}$. Here, we describe the cell ultrastructure, physiological properties and metabolic pathways of this methanotrophic bacterium, as well as its biochemical, chemotaxonomic and genotypic features. We propose a novel genus and species, Methylocapsa acidiphila gen. nov., sp. nov., for this strain.

\section{METHODS}

Methanotrophic community and culture conditions. The methanotrophic community was enriched from an acidic peat bog ( $\mathrm{pH} 3 \cdot 6-4 \cdot 5)$ underlying a Sphagnum-Carex plant community (Bakchar bog, Plotnikovo field station in West Siberia, $56^{\circ} \mathrm{N}, 82^{\circ} \mathrm{E}$ ) as described previously using nitrogenfree M2 medium at pH 4.0-4.5 (Dedysh et al., 1998a). This community was grown in 120 -ml serum bottles containing $25 \mathrm{ml} \mathrm{M} 2$ nitrogen-free medium at $\mathrm{pH} 4 \cdot 1$. After inoculation, methane was added aseptically through silicone rubber septa to achieve a gas-mixing ratio in the headspace of approximately $25 \%$. The bottles were then incubated for 1 week at $24^{\circ} \mathrm{C}$ and shaken at 200 r.p.m.

Isolation and maintenance of methane-oxidizing strain $\mathrm{B2}^{\top}$. Cell suspensions of the exponentially growing Bakchar microbial community were serially diluted in tenfold steps in nitrogen-free M2 medium of $\mathrm{pH}$ 4.5-5.0 using screw-cap 35$\mathrm{ml}$ serum vials with a headspace/liquid space ratio of $6: 1$. After inoculation, methane was added aseptically to attain a final mixing ratio of approximately $25 \%$. The inoculated vials were then incubated at $24^{\circ} \mathrm{C}$ and 200 r.p.m. The cultures were examined by phase-contrast microscopy and, if morphologically uniform, the cells were transferred to fresh medium and grown again under the same growth conditions. After repeating this process of serial dilution 20 times over 2 years, a methane-oxidizing isolate was purified, designated strain $\mathrm{B}^{\mathrm{T}}$. Once isolated, this bacterium was maintained in nitrogen-free M2 medium and was subcultured at 2-3 week intervals.

Verification of purity of strain $\mathbf{B 2}^{\top}$. Both phase-contrast and electron microscopy were used to examine cultures of strain $\mathrm{B} 2^{\mathrm{T}}$ for contamination throughout the various stages of growth as well as under different cultivation conditions $(\mathrm{pH}$ range of 4 to 6 , nitrogen-free and nitrogen-sufficient M2 media). The absence of heterotrophic satellite colonies was confirmed by plating $\mathrm{B} 2^{\mathrm{T}}$ culture on several media containing different organic substrates. These were standard undiluted and tenfold-diluted Luria-Bertani agar $[1.0 \%$ (w/v) tryptone, $0.5 \%(\mathrm{w} / \mathrm{v})$ yeast extract, $1.0 \%(\mathrm{w} / \mathrm{v}) \mathrm{NaCl}]$ and $\mathrm{M} 2$ agar media $[1.5 \%(\mathrm{w} / \mathrm{v})$ Noble agar] amended with $0.1 \%$ $(\mathrm{w} / \mathrm{v})$ glucose, fructose or sucrose. Examination of the $\mathrm{B} 2^{\mathrm{T}}$ culture for the presence of heterotrophic satellites was also performed using liquid M2 media supplemented with the following carbon sources at $0.05 \%(\mathrm{w} / \mathrm{v})$ : glucose, fructose, sucrose, galactose, arabinose, ribose, lactate, pyruvate, citrate, acetate, succinate, ethanol and mannitol. To ensure detection of slowly growing heterotrophic satellites, growth was assessed after 4 weeks of incubation at $24^{\circ} \mathrm{C}$ and 200 r.p.m.

Morphological observations. Cell morphology and the presence of cysts or exospores were examined by using batch cultures grown to the early-exponential, late-exponential and stationary growth phases. The Gram-stain reaction and lysis in 3\% (w/v) KOH (Gerhardt, 1981) were tested with both 1 - and 3-week-old cultures. Lysis by 0.2 and $2 \%(\mathrm{w} / \mathrm{v})$ SDS was determined by direct microscopic observation.

Electron microscopy. Preparation of thin sections and electron microscopy were done as described previously (Khmelenina et al., 1997, 1999). For freeze-fractured preparations, exponentially growing cells were collected and frozen in liquid propane cooled to $-196^{\circ} \mathrm{C}$ with liquid nitrogen. Cells were fractured according to Suzina et al. (1995) in a JEE-4X vacuum evaporator at $3 \times 10^{-4} \mathrm{~Pa}$ and a sample temperature of $-100^{\circ} \mathrm{C}$. The fracture faces were shadowed with a platinum/carbon mixture and coated with carbon. Replicas and ultrathin sections were imaged in a JEM-100B transmission electron microscope operating at $60 \mathrm{kV}$.

Effect of pH on growth of strain B2 ${ }^{\mathrm{T}}$. Cells of strain $\mathrm{B} 2^{\mathrm{T}}$, growing exponentially at $\mathrm{pH} 5 \cdot 0$, were collected by centrifugation, washed twice with fresh nitrogen-free M2 medium and inoculated into $120-\mathrm{ml}$ serum bottles containing $25 \mathrm{ml}$ nitrogen-free $\mathrm{M} 2$ medium at $\mathrm{pH}$ values ranging from 3.9 to $8 \cdot 0$. To maintain constant ionic strength with varying $\mathrm{pH}$, $0 \cdot 1 \mathrm{M}$ solutions of $\mathrm{H}_{3} \mathrm{PO}_{4}, \mathrm{KH}_{2} \mathrm{PO}_{4}$ and $\mathrm{K}_{2} \mathrm{HPO}_{4}$ were used. After inoculation and addition of methane, the samples were incubated for $10 \mathrm{~d}$ at $24^{\circ} \mathrm{C}$ and 200 r.p.m. Growth, monitored by nephelometry at $410 \mathrm{~nm}$, and $\mathrm{pH}$ of the culture were measured over time in triplicate bottles.

Other physiological tests. Growth of strain $\mathrm{B} 2^{\mathrm{T}}$ was monitored for 2 weeks with methane as the sole growth substrate under a variety of conditions, including temperatures ranging from 4 to $37^{\circ} \mathrm{C}$ and $\mathrm{NaCl}$ at concentrations of $0 \cdot 01-1 \%$ (w/v) using liquid cultures. The ability to grow under microaerobic conditions was also determined in growth experiments with $5 \% \mathrm{O}_{2}(\mathrm{v} / \mathrm{v})$ in the headspace of incubation flasks.

Range of utilizable carbon and nitrogen sources. The 
following carbon sources at $0 \cdot 05 \%(\mathrm{w} / \mathrm{v})$ were examined to determine the range of potential growth substrates of strain $\mathrm{B} 2^{\mathrm{T}}$ : formate, formamide, urea, methylamine, dimethylamine, trimethylamine, tetramethylammonium chloride, ethanol, glucose, fructose, sucrose, galactose, arabinose, ribose, lactate, pyruvate, citrate, acetate, succinate and mannitol. The capacity to utilize methanol at concentrations from 0.01 to $1 \%(\mathrm{v} / \mathrm{v})$ was determined on M2 medium. Nitrogen sources were also tested using M2 medium with addition of the following compounds at $0.02 \%(\mathrm{w} / \mathrm{v})$ : $\mathrm{NaNO}_{2},\left(\mathrm{NH}_{4}\right)_{2} \mathrm{SO}_{4}$, DL-alanine, glycine, L-serine, L-threonine, L-valine, L-leucine, L-isoleucine, L-proline, L-cysteine, L-methionine, L-glutamate, L-aspartate, L-glutamine, L-asparagine, L-histidine, L-phenylalanine, L-tryptophan, Larginine, L-lysine, L-ornithine, L-citrulline and yeast extract. Growth was examined after 2 weeks of incubation and confirmed by comparison with growth on nitrogen-free M2 medium.

Naphthalene assay of sMMO activity. In order to monitor sMMO activity, the naphthalene assay developed by Brusseau et al. (1990) was used as described previously (Lontoh \& Semrau, 1998) for all methanotrophic reference strains as well as the novel methanotrophic isolate, strain $\mathrm{B} 2^{\mathrm{T}}$.

Acetylene-reduction assay of nitrogen-fixation activity. $\mathrm{Ni}$ trogen fixation was assayed on nitrogen-free M2 medium with batch cultures in the mid-exponential growth phase by using the acetylene-reduction procedure of Takeda (1988). Prior to injection of acetylene, the incubation flasks were divided into two groups. One group of flasks was flushed with sterile air to remove any remaining methane, whereas the other flasks were purged with sterile dinitrogen to remove methane and oxygen, with oxygen subsequently being added by syringe to a $5 \%(\mathrm{v} / \mathrm{v})$ mixing ratio in the headspace. Methanol was added to the flasks at a concentration of $0.05 \%(\mathrm{v} / \mathrm{v})$. The amount of ethylene produced was measured after $3 \mathrm{~h}$ incubation on a rotary shaker (200 r.p.m.) at $24{ }^{\circ} \mathrm{C}$.

Reference bacterial strains. Methylosinus trichosporium $\mathrm{OB}^{\mathrm{T}} \mathrm{b}^{\mathrm{T}}\left(=\mathrm{ATCC} 35070^{\mathrm{T}}\right)$, Methylococcus capsulatus Bath (=ATCC 33009), Methylocella palustris $\mathrm{K}^{\mathrm{T}}$ (= ATCC 700799 $)$, 'Methylobacter bovis' 89 and Methylosinus trichosporium 19 were used as reference strains. The last two strains were obtained from the collection of methanotrophic bacteria of the Institute of Biochemistry and Physiology of Microorganisms (Pushchino, Russia). All the methanotrophic strains except Methylocella palustris $\mathrm{K}^{\mathrm{T}}$ were cultivated on NMS medium with methane as the growth substrate (Whittenbury et al., 1970a). Methylocella palustris $\mathrm{K}^{\mathrm{T}}$ was grown on $\mathrm{M} 2$ medium supplemented with vitamins (Dedysh et al., 2000).

Analytical techniques. $\mathrm{CH}_{4}$ and $\mathrm{C}_{2} \mathrm{H}_{4}$ were measured with a GC equipped with a flame-ionization detector. $\mathrm{CO}_{2}$ and $\mathrm{O}_{2}$ were analysed by $\mathrm{GC}$ with a thermoconductivity detector. All measurements were performed using triplicate samples.

DNA isolation and characterization. Genomic DNA from strain $\mathrm{B}^{\mathrm{T}}$ was extracted using the SDS-based assay as described previously (Dedysh et al., 1998a). The DNA base composition of strain $\mathrm{B} 2^{\mathrm{T}}$ was determined by thermal denaturation using a Unicam SP1800 spectrophotometer at a heating rate of $0.5{ }^{\circ} \mathrm{C} \mathrm{min}^{-1}$. The $\mathrm{G}+\mathrm{C}$ content was calculated with the equation of Owen et al. (1969): $\mathrm{G}+\mathrm{C}$ content $(\mathrm{mol} \%)=2 \cdot 08 T_{\mathrm{m}}-106 \cdot 4$. DNA of Escherichia coli $\mathrm{K}-12$ was used as the standard. DNA-DNA hybridization of strain $\mathrm{B} 2^{\mathrm{T}}$ and Methylocella palustris $\mathrm{K}^{\mathrm{T}}$ was done on nitrocellulose membrane filters (Hybond-N, Amersham) according to Lysenko et al. (1988). Genomic DNA fractions were labelled using deoxy[1 $\left.1^{\prime}, 2^{\prime}, 5^{\prime}-{ }^{3} \mathrm{H}\right]$ cytidine $5^{\prime}$-triphosphate and the nick translation kit N 5500 following the manufacturer's instructions (Amersham; Technical Bulletin, 1980). Hybridization was performed with five replications in an incubation mixture containing $2 \times \mathrm{SSC}(0 \cdot 3 \mathrm{M} \mathrm{NaCl}$, $0.03 \mathrm{M}$ trisodium citrate, $\mathrm{pH} 7 \cdot 0)$ and $50 \%(\mathrm{v} / \mathrm{v})$ formamide at $49{ }^{\circ} \mathrm{C}$ for $24 \mathrm{~h}$.

Comparative sequence analysis of the 16S rRNA gene. PCRmediated amplification of the 16S rRNA gene from positions 28 to 1491 (numbering according to the International Union of Biochemistry nomenclature for Escherichia coli $16 \mathrm{~S}$ rRNA), sequencing and phylogenetic inference were carried out as described for Methylocella palustris $\mathrm{K}^{\mathrm{T}}$ (Dedysh et al., 1998b, 2000).

Whole-cell fatty acid and phospholipid analysis. Fatty acid analyses for both Methylocella palustris $\mathrm{K}^{\mathrm{T}}$ and strain $\mathrm{B} 2^{\mathrm{T}}$ were performed by Microbial Insights, Inc. (Rockford, TN, USA). Extractions were performed using one-phase chloroform/methanol/buffer extractant. Lipids were recovered, dissolved in chloroform and fractionated on disposable silicic acid columns into neutral-, glyco- and polar-lipid fractions. The polar lipid fraction was transesterified with mild alkali to recover the phospholipid ester-linked fatty acids (PLFA) as methyl esters in hexane. PLFA were analysed by GC with peak confirmation performed by electron impact mass spectrometry.

Intact phospholipid profiles were prepared as described previously (Fang et al., 2000). Phospholipids were extracted overnight at $4{ }^{\circ} \mathrm{C}$ from liquid cultures using a 2:1:0.8 mixture of methanol, dichloromethane (DCM) and phosphate buffer. Lipids were then partitioned into organic solvent by adding DCM and water such that the final $\mathrm{DCM} / \mathrm{methanol} /$ water ratio was $1: 1: 0 \cdot 9$. The organic phase was then filtered and the total lipid extract was dried and redissolved in methanol. Intact phospholipid profiles were determined using liquid chromatography/electrospray ionization-mass spectrometry analysis with an HP 1090 liquid chromatography/HP 5989B single quadrupole mass spectrometer with an electrospray interface. The concentrations of phospholipids were calculated based on the chromatographic area response of individual phospholipids relative to that of an internal standard (18:1-lyso-phosphatidylglycerol) and reported as $\mu \mathrm{g} \mathrm{ml}^{-1}$ liquid culture. The reproducibility of the analysis was better than $87 \%(n=5)$.

Enzyme assays. Enzymic studies were performed as described for Methylocella palustris $\mathrm{K}^{\mathrm{T}}$ (Dedysh et al., 2000).

\section{RESULTS}

\section{Isolation and cell morphology of the methane- oxidizing strain $\mathrm{B}^{\mathrm{T}}$}

Despite the large spectrum of $\mathrm{pH}$ and incubation conditions, all attempts to isolate MOB from the Bakchar community by surface plating were unsuccessful. However, the isolation of the methanotrophic strain $\mathrm{B} 2^{\mathrm{T}}$ in pure culture was achieved by using multiple repeated serial dilutions in liquid medium. Cells of strain $\mathrm{B} 2^{\mathrm{T}}$ were Gram-negative, non-motile, curved coccoids, $0 \cdot 7-1 \cdot 0 \mu \mathrm{m}$ in width and $0 \cdot 8-1 \cdot 2 \mu \mathrm{m}$ in 

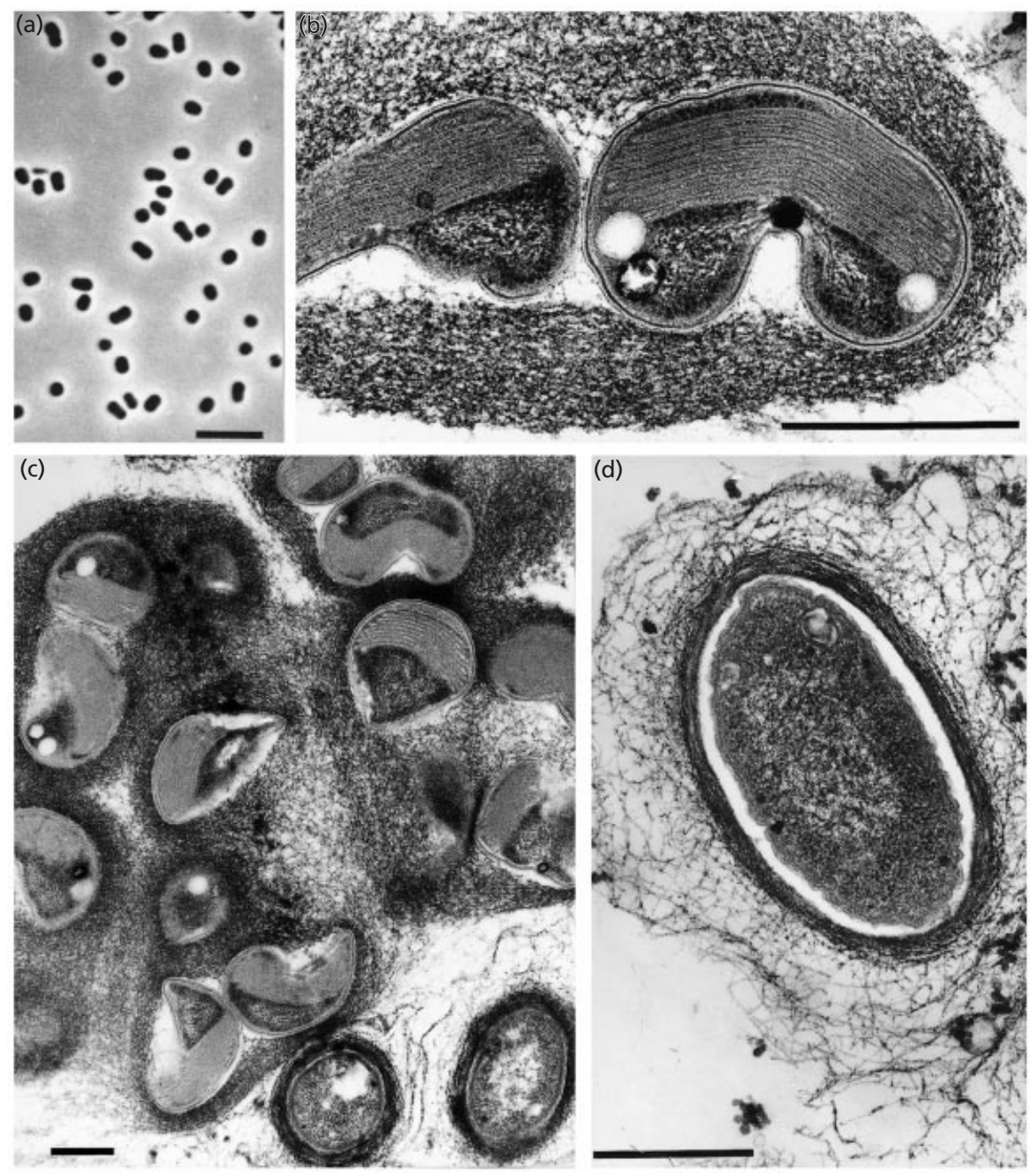

Fig. 1. (a) Phase-contrast micrograph of strain $B 2^{\top}$ grown on methane for $4 \mathrm{~d}$ at $\mathrm{pH} 4 \cdot 5$. Bar, $5 \mu \mathrm{m}$. (b) Negatively stained thin section of vegetative cells of strain $B 2^{\top}$ prefixed by ruthenium red. Cells are included in a fibrous polysaccharide matrix. Bar, $0.5 \mu \mathrm{m}$. (c) Negatively stained thin section of cellular aggregates of strain B2 prefixed with ruthenium red. Vegetative cells with well-developed ICM and PHB granules are included in the polysaccharide matrix. Separate lipid cysts without ICM structures are located on the periphery of the vegetative cell conglomerates. Bar, $0.5 \mu \mathrm{m}$. (d) Thin section of a cyst of strain $B 2^{\top}$. Bar, $0.5 \mu \mathrm{m}$.

length (Fig. 1a), that reproduced by binary fission with cross constriction formation. Cells occurred singly or formed aggregates that were surrounded by an extracellular matrix of polysaccharide (Fig. 1b, c) as revealed by contrasting the acid mucopolysaccharides with ruthenium red (Luft, 1964).

\section{Characterization of growth}

Strain $\mathrm{B} 2^{\mathrm{T}}$ grew in liquid mineral media only and did not form colonies on solid media made with any purity grade agar or with agarose. Liquid cultures displayed a white turbidity that mostly sedimented and a surface pellicle was not formed. Cellular conglomerates were predominantly formed when cells were grown in acidic conditions on nitrogen-free media.

\section{Cell ultrastructure}

A well-developed system of ICM was revealed in thin sections of the cells (Fig. 1b, c). Extended layers of membrane vesicles were packed in parallel to each other on only one side of the cell membrane. The number of membrane vesicles was approximately seven to ten per cell. Freeze-fractured preparations showed an intermediate type of ICM arrangement in cells of strain $\mathrm{B} 2^{\mathrm{T}}$ in comparison with the characteristic type I ICM arrangement (stacks of vesicles) in 

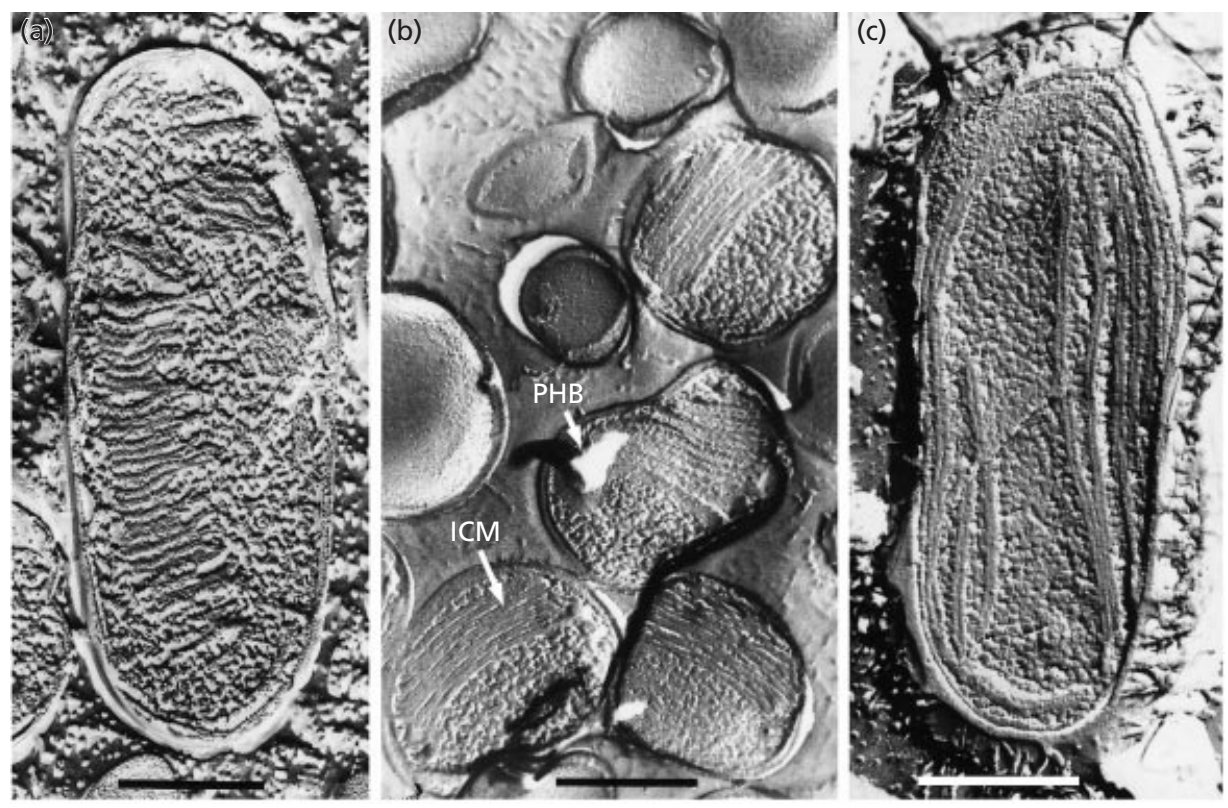

Fig. 2. Freeze-fractured cells of 'Methylobacter bovis' 89 (a), strain $B 2^{\top}$ (b) and Methylosinus trichosporium 19 (c) with characteristic type I, intermediate type and type II ICM arrangements. Bars, $0.5 \mu \mathrm{m}$.

'Methylobacter bovis' 89 and type II ICM arrangement (peripherally and loosely arranged membranes aligned parallel to cytoplasmic membrane) in Methylosinus trichosporium 19 (Fig. 2). Intracellular inclusions were observed as low electron-transparent spherical granules of poly- $\beta$-hydroxybutyrate (PHB), which was confirmed by freeze-fracture methods (Dunlop \& Robards, 1973). PHB in the granules was stretched during cutting, as seen on the freeze-etched preparations (Fig. 2b).

As seen in thin sections, the cells formed a large amount of extracellular polysaccharide matrix, revealed by contrasting the acid mucopolysaccharides with ruthenium red. Several methanotrophic cells were found embedded in this matrix, implying that cell division occurred inside the matrix. On the periphery of the cellular aggregates, but included in the matrix, were morphologically different cells (Fig. 1c, d). These cells did not possess complex membrane systems and were surrounded by an additional two-layered envelope or coat. The inner part of the envelope near the outer membrane of these cells contained closely packed fibrillae with high electron density. The more extensive outer coat also consisted of fibrillae but had lower electron density. These cells are apparently the resting stage of the bacterium and are more similar to the cysts of the Azotobacter-like type than to the 'lipid cysts' formed by representatives of the genus Methylocystis.

\section{Purity criteria}

Microscopic checks confirmed the uniform cell morphology of strain $\mathrm{B} 2^{\mathrm{T}}$ at different stages of culture development and under different growth conditions
(pH 4.5, $5 \cdot 5$ and 6.5 as well as growth on nitrogen-free and nitrogen-sufficient media). Electron microscopy examinations also failed to reveal any contamination of isolate $\mathrm{B} 2^{\mathrm{T}}$ by other bacteria. Finally, no growth was obtained on complex organic media or basal medium M2 supplemented with individual sugars.

\section{Physiological characteristics}

Strain $\mathrm{B}^{\mathrm{T}}$ was capable of growth on methane and methanol as the sole carbon and energy sources. Methanol supported growth only when used at concentrations below $0.05 \%(\mathrm{v} / \mathrm{v})$. We did not observe growth either on other $\mathrm{C}_{1}$ substrates or on the range of multicarbon compounds tested. Growth factors were not required. Strain $\mathrm{B}^{\mathrm{T}}$ utilized ammonium salts, nitrates and yeast extract as nitrogen sources, although it was able to fix atmospheric nitrogen and grew well in nitrogen-free medium. The acetylene reduction activity of strain $\mathrm{B}^{\mathrm{T}}$ in microaerobic conditions ranged from $5 \cdot 7$ to $7 \cdot 0 \mathrm{nmol} \mathrm{C}_{2} \mathrm{H}_{4}$ (mg dry biomass) ${ }^{-1} \mathrm{~h}^{-1}$, while under aerobic conditions it fell to $0 \cdot 2-0 \cdot 3 \mathrm{nmol} \mathrm{C}_{2} \mathrm{H}_{4}$ (mg dry biomass $)^{-1} \mathrm{~h}^{-1}$.

sMMO activity, as determined by the production of naphthol from naphthalene, was never observed in strain $\mathrm{B} 2^{\mathrm{T}}$. The isolate grew in the $\mathrm{pH}$ range $4 \cdot 2-7 \cdot 2$ with the optimum at $\mathrm{pH} 5 \cdot 0-5 \cdot 5$. The temperature range for growth was $10-30{ }^{\circ} \mathrm{C}$ with the optimum at approximately $20^{\circ} \mathrm{C}$; no growth occurred at $37^{\circ} \mathrm{C}$. The generation time was in the range 15-40 h. Similar to Methylocella palustris, strain $\mathrm{B}^{\mathrm{T}}$ grew in media with low salt content (up to $1-1.5 \mathrm{~g} \mathrm{l}^{-1}$ ), while the optimum salt concentrations were in the range $0 \cdot 2$ 
Table 1. Cellular fatty acid compositions of the novel acidophilic methanotroph $\mathrm{B2}^{\top}$, Methylocella palustris $\mathrm{K}^{\top}$ and other type II methanotrophs

Taxa are indicated as: 1, Methylocapsa acidiphila $\mathrm{B}^{\mathrm{T}} ; 2$, Methylocella palustris $\mathrm{K}^{\mathrm{T}} ; 3$, Methylosinus and Methylocystis spp. Values are percentages of total fatty acids. br, Branched; cy, cyclo.

\begin{tabular}{|lllr|}
\hline Fatty acid & $\mathbf{1}$ & $\mathbf{2}$ & \multicolumn{1}{c|}{$\mathbf{3}^{*}$} \\
\hline $\mathrm{i} 15: 0$ & $0 \cdot 1$ & $0 \cdot 2$ & $0-0 \cdot 9$ \\
$\mathrm{a} 15: 0$ & 0 & 0 & $0-3 \cdot 5$ \\
$15: 0$ & 0 & $0 \cdot 1$ & $0-0 \cdot 7$ \\
$\mathrm{i} 16: 0$ & 0 & 0 & $0-1 \cdot 4$ \\
$16: 1 \omega 7 c$ & $4 \cdot 7$ & $6 \cdot 8$ & $0 \cdot 3-14 \cdot 2$ \\
$16: 1 \omega 7 t$ & 0 & $5 \cdot 8$ & 0 \\
$16: 1 \omega 6 c$ & 0 & 0 & $0-0 \cdot 3$ \\
$16: 1 \omega 5 c$ & $0 \cdot 1$ & $0 \cdot 1$ & $0-0 \cdot 2$ \\
$16: 0$ & $7 \cdot 3$ & $5 \cdot 9$ & $0 \cdot 7-5 \cdot 1$ \\
$\mathrm{i} 17: 1 \omega 7 c$ & 0 & $0 \cdot 1$ & 0 \\
$\mathrm{i} 17: 0$ & $0 \cdot 6$ & 0 & $0-0 \cdot 3$ \\
$\mathrm{a} 17: 0$ & 0 & $0 \cdot 3$ & $0-0 \cdot 6$ \\
$17: 1 \omega 8 c$ & 0 & $0 \cdot 3$ & $0-0 \cdot 2$ \\
$17: 1 \omega 7 c$ & $1 \cdot 0$ & 0 & $0-0 \cdot 7$ \\
$17: 1 \omega 6 c$ & 0 & $0 \cdot 1$ & $0-0 \cdot 1$ \\
$17: 0$ & $0 \cdot 1$ & $0 \cdot 1$ & $0-0 \cdot 4$ \\
cy $18: 0$ & 0 & 0 & $0-6 \cdot 5$ \\
$18: 1 \omega 8 c$ & 0 & 0 & $52 \cdot 9-73 \cdot 6$ \\
$18: 1 \omega 7 c$ & $78 \cdot 3$ & $78 \cdot 6$ & $14 \cdot 8-37 \cdot 7$ \\
$18: 1 \omega 7 t$ & 0 & 0 & $0-4 \cdot 6$ \\
$18: 1 \omega 5 c$ & 0 & $0 \cdot 1$ & $0-0 \cdot 2$ \\
$18: 0$ & $7 \cdot 6$ & $0 \cdot 9$ & $0-5 \cdot 0$ \\
$\mathrm{br} 19: 1$ & 0 & 0 & $0-0 \cdot 2$ \\
$\mathrm{cy} 19: 0$ & 0 & 0 & $0-0 \cdot 4$ \\
\hline
\end{tabular}

* Data taken from Bowman et al. (1993).

$0 \cdot 5 \mathrm{~g}^{-1}$. Growth was inhibited completely in the presence of $\mathrm{NaCl}$ at concentrations above $0.5 \%(\mathrm{w} / \mathrm{v})$.

\section{Cellular fatty acid and phospholipid profiles}

The cellular fatty acid composition was determined for both strain $\mathrm{B}^{\mathrm{T}}$ and Methylocella palustris $\mathrm{K}^{\mathrm{T}}$ (Table 1). These two methanotrophs possessed highly similar PLFA profiles. The major component of their profiles was $18: 1 \omega 7 c$ fatty acid, which comprised $78 \%$ of the total PLFAs. Interestingly, both organisms lacked 18: $1 \omega 8 c$, a common and specific fatty acid for the genera Methylosinus and Methylocystis (Guckert et al., 1991; Bowman et al., 1993).

Although similar, the PLFA profiles of strain $\mathrm{B} 2^{\mathrm{T}}$ and Methylocella palustris $\mathrm{K}^{\mathrm{T}}$ were not identical. The total content of 16-carbon fatty acids in Methylocella palustris $\mathrm{K}^{\mathrm{T}}$ exceeded the corresponding value in strain $\mathrm{B} 2^{\mathrm{T}}$. Specifically, strain $\mathrm{B} 2^{\mathrm{T}}$ possessed $16: 1 \omega 7 \mathrm{c}$ acid only, while Methylocella palustris $\mathrm{K}^{\mathrm{T}}$ contained both

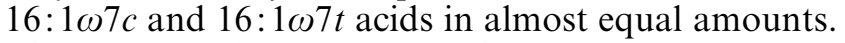
The content of 18:0 fatty acid was also significantly
Table 2. Activities of the enzymes of primary and intermediate metabolism in cell extracts of strain $\mathrm{B}^{\top}$

Activities are given in $\mathrm{nmol} \mathrm{min}^{-1}(\mathrm{mg} \text { protein })^{-1}$.

\begin{tabular}{|c|c|c|}
\hline Enzyme & Cofactor* & Activity \\
\hline sMMO & - & 0 \\
\hline pMMO & - & 100 \\
\hline Methanol dehydrogenase & PMS & 219 \\
\hline \multirow[t]{2}{*}{ Formaldehyde dehydrogenase } & PMS & 20 \\
\hline & GSH, NAD & 0 \\
\hline \multirow[t]{2}{*}{ Formate dehydrogenase } & PMS & 42 \\
\hline & NAD & 28 \\
\hline $\begin{array}{l}\text { Ribulose-1,5-bisphosphate } \\
\text { carboxylase }\end{array}$ & - & 0 \\
\hline Hexulose-phosphate synthase & - & 0 \\
\hline \multirow[t]{2}{*}{ 6-Phosphofructokinase } & ATP & 0 \\
\hline & PPi & 75 \\
\hline Fructose-1,6-bisphosphate aldolase & - & 43 \\
\hline \multirow{2}{*}{ Glucose-6-phosphate dehydrogenase } & NAD & 0 \\
\hline & NADP & 32 \\
\hline \multirow[t]{2}{*}{ 6-Phosphogluconate dehydrogenase } & NAD & 16 \\
\hline & NADP & 33 \\
\hline KDPG aldolase & - & 0 \\
\hline \multirow{2}{*}{ Hydroxypyruvate reductase } & $\mathrm{NADH}$ & 38 \\
\hline & NADPH & 0 \\
\hline Serine-glyoxylate aminotransferase & - & 33 \\
\hline Pyruvate kinase & - & 0 \\
\hline Pyruvate dehydrogenase & NAD & 0 \\
\hline \multirow[t]{2}{*}{ Isocitrate dehydrogenase } & NAD & 46 \\
\hline & NADP & 40 \\
\hline$\alpha$-Ketoglutarate dehydrogenase & NAD & 13 \\
\hline Malate dehydrogenase & NAD & 19 \\
\hline \multirow[t]{2}{*}{ Glutamate dehydrogenase } & NAD & 0 \\
\hline & NADP & 0 \\
\hline \multirow[t]{2}{*}{ Glutamate synthase } & $\mathrm{NADH}$ & 33 \\
\hline & NADPH & 0 \\
\hline Glutamine synthetase & ATP, $\mathrm{Mn}^{2+}$ & 92 \\
\hline
\end{tabular}

* GSH, Reduced glutathione; PMS, phenazine methosulfate; $\mathrm{PPi}$, pyrophosphate.

higher in $\mathrm{B}^{\mathrm{T}}$ than in Methylocella palustris $\mathrm{K}^{\mathrm{T}}$. Another distinctive feature of the strain $\mathrm{B} 2^{\mathrm{T}}$ PLFA profile was the presence of $17: 1 \omega 7 c$ and i17:0 fatty acids, which are not common for type II methanotrophs.

The intact phospholipid profile analyses showed that strain $\mathrm{B} 2^{\mathrm{T}}$ and Methylocella palustris $\mathrm{K}^{\mathrm{T}}$ have significantly different phospholipids. The major phospholipids $(63 \%)$ in strain B2 ${ }^{\mathrm{T}}$ were phosphatidylglycerols, which were not detected in Methylocella palustris $\mathrm{K}^{\mathrm{T}}$. The minor phospholipids in strain $\mathrm{B} 2^{\mathrm{T}}$ were phosphatidylethanolamines $(17 \%)$ and phosphatidylmethylethanolamines $(3 \cdot 5 \%)$. In contrast to strain B2 ${ }^{\mathrm{T}}, 94 \%$ of the total phospholipids in Methylocella palustris $\mathrm{K}^{\mathrm{T}}$ were represented by phosphatidylmethylethanolamine (Fang et al., 2000). 


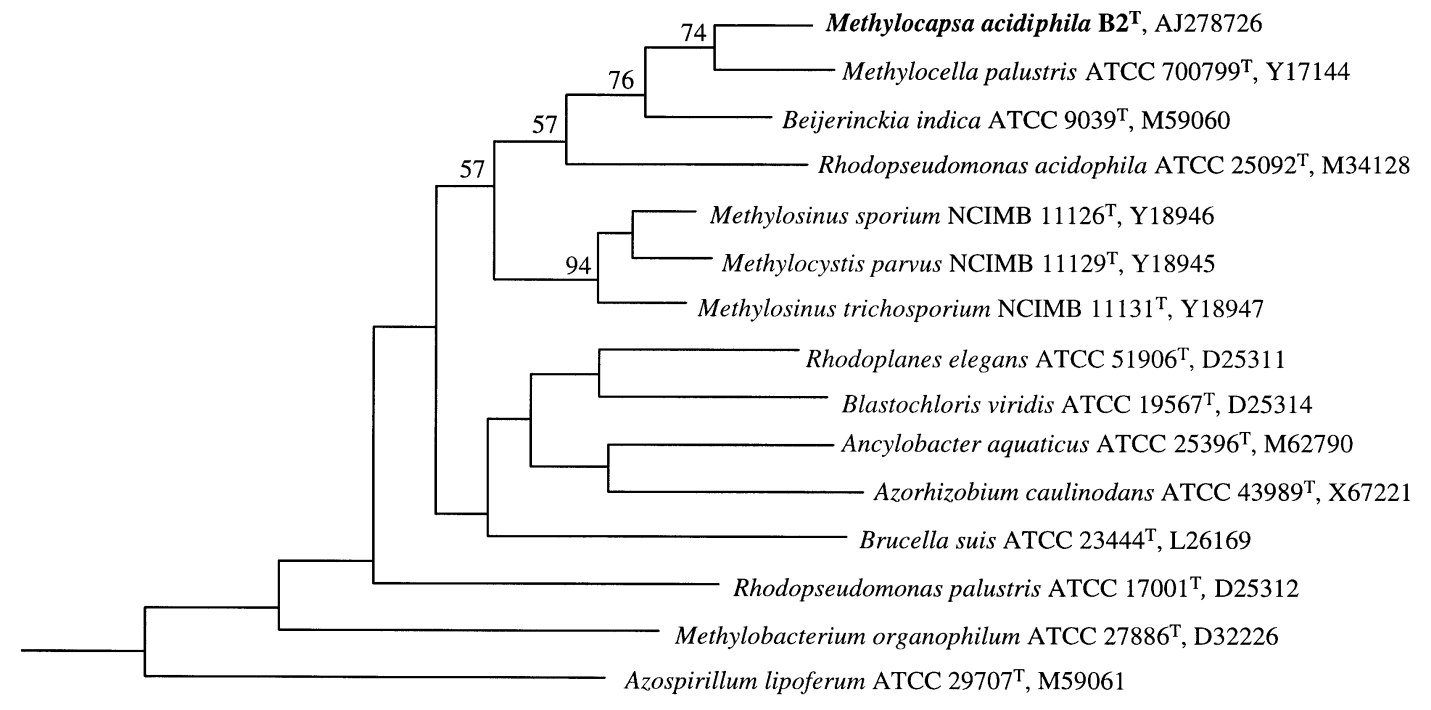

0.05

Fig. 3. $16 \mathrm{~S}$ rDNA-based dendrogram showing the phylogenetic position of strain $B 2^{\top}$ in relation to Methylocella palustris $\mathrm{K}^{\top}$ and other representative members of the $\alpha$-subclass of the Proteobacteria. The dendrogram was reconstructed by using distance matrix methods [calculation of the distance matrix with the equation of Jukes \& Cantor (1969) and construction of the distance tree by the neighbour-joining method (Saitou \& Nei, 1987)]. Numbers indicate the percentage significance values for interior nodes, as derived from a bootstrap test in which 1000 data resamplings were used. The root was determined by using the $16 \mathrm{~S}$ rDNA sequence of the $\gamma$-proteobacterium Methylococcus capsulatus as the outgroup reference. Bar, 0.05 substitutions per nucleotide sequence position.

\section{Enzymological analysis}

The methane-oxidizing activity was mainly located in the ICM, since sMMO was not expressed by strain $\mathrm{B} 2^{\mathrm{T}}$. The other enzyme activities involved in the sequential oxidation of $\mathrm{CH}_{4}$ to $\mathrm{CO}_{2}$ (dehydrogenases of methanol, formaldehyde and formate) were also observed, as shown in Table 2. Activities of both hydroxypyruvate reductase and serine-glyoxylate aminotransferase were revealed, indicating that strain $\mathrm{B}^{\mathrm{T}}$ assimilates formaldehyde via the serine pathway. Activities of the Calvin cycle enzymes (phosphoribulokinase and ribulose-bisphosphate carboxylase) as well as the key ribulose monophosphate cycle enzyme (hexulose-phosphate synthase) were not found. The presence of $\alpha$-ketoglutarate dehydrogenase indicated that the complete tricarboxylic acid cycle operates in this bacterium. The glyoxylate shunt enzymes, isocitrate lyase and malate synthase, were not detectable. Relatively high activities were found of the pentose phosphate cycle enzymes glucose-6-phosphate dehydrogenase and 6-phosphogluconate dehydrogenase. The finding of pyrophosphate-dependent 6-phosphofructokinase and fructose-1,6-bisphosphate aldolase activities suggested carbohydrate metabolism through the reversible glycolytic sequence. However, no activity of pyruvate kinase was detected. Finally, strain B2 ${ }^{\mathrm{T}}$ used the glutamate cycle enzymes, glutamine synthetase and glutamate synthase, for ammonium assimilation. In general, the metabolic pattern of this acidophilic strain was the same as in other neutrophilic type II methanotrophs that possess the isocitrate lyasenegative variant of the serine pathway.

\section{Phylogenetic analysis and DNA-DNA reassociation study}

Comparative sequence analysis of the 16S rRNA gene showed that strain $\mathrm{B} 2^{\mathrm{T}}$ is most closely related to the acidophilic methane-oxidizing bacterium Methylocella palustris $\mathrm{K}^{\mathrm{T}}$, a member of the $\alpha$-subclass of the Proteobacteria (Fig. 3). The overall 16S rDNA sequence similarity between strain $\mathrm{B} 2^{\mathrm{T}}$ and Methylocella palustris $\mathrm{K}^{\mathrm{T}}$ is $97.3 \%$. The next closest related microorganism is the non-methanotrophic bacterium Beijerinckia indica subsp. indica, which exhibits overall $16 \mathrm{~S}$ rDNA sequence similarity of 96.2 and $96.5 \%$ to strain $\mathrm{B} 2^{\mathrm{T}}$ and Methylocella palustris $\mathrm{K}^{\mathrm{T}}$, respectively.

The DNA G + C content of strain $\mathrm{B} 2^{\mathrm{T}}$ was $63 \cdot 1 \mathrm{~mol} \%$. The DNA-DNA hybridization value of strain $\mathrm{B} 2^{\mathrm{T}}$ and Methylocella palustris $\mathrm{K}^{\mathrm{T}}$ was $7 \%$, while the homologous DNA fractions showed 100\% hybridization.

\section{DISCUSSION}

Given all the characteristic features of $\mathrm{B} 2^{\mathrm{T}}$, we believe that this novel acidophilic isolate should be classified as a type II methanotrophic bacterium. It is the second culturable representative of the novel subtype of serine-pathway methanotrophs to which Methylocella palustris $\mathrm{K}^{\mathrm{T}}$ also belongs. Strain $\mathrm{B} 2^{\mathrm{T}}$ displayed pheno- 
typic traits very similar to those of Methylocella palustris $\mathrm{K}^{\mathrm{T}}$, e.g. $\mathrm{pH}$ and temperature ranges for growth, as well as sensitivity to salt stress. These traits are defined by the physico-chemical characteristics of the acidic, oligotrophic habitat from which both methanotrophs were isolated. However, a closer look at many of the other key features showed that these two methanotrophs should be considered two different taxa.

Both the cell morphology and ultrastructure of strain $\mathrm{B} 2^{\mathrm{T}}$ were profoundly different from those of Methylocella palustris $\mathrm{K}^{\mathrm{T}}$. The different cell shape, lack of bipolar cell appearance and formation of cellular conglomerates covered by a polysaccharide matrix made strain $\mathrm{B} 2^{\mathrm{T}}$ clearly distinguishable from Methylocella palustris $\mathrm{K}^{\mathrm{T}}$. Also, the types of resting cells formed by strain $\mathrm{B}^{\mathrm{T}}$ and Methylocella palustris $\mathrm{K}^{\mathrm{T}}$ were clearly different. Methylocella palustris $\mathrm{K}^{\mathrm{T}}$ was shown to form exospores, while strain $\mathrm{B} 2^{\mathrm{T}}$ formed an unusual type of cyst. The ultrastructure of these cysts somewhat resembled the 'lipid cysts' of Methylocystis parvus (Wittenbury et al., 1970b). The key difference, however, was the presence of an additional extensive outer coat in the cysts of strain $\mathrm{B} 2^{\mathrm{T}}$. The structure of these resting cells was more similar to the Azotobacterlike cysts that are characteristic of type I methanotrophs. However, the structure differed from the Azotobacter-like cysts in the presence of outer cell membranes and the presence of intine (inner wall as a thick homogeneous layer) (Socolofsky \& Wyss, 1961).

The most striking ultrastructural distinction between strain $\mathrm{B}^{\mathrm{T}}$ and Methylocella palustris $\mathrm{K}^{\mathrm{T}}$ was that strain $\mathrm{B}^{\mathrm{T}}$, like most of the other known $\mathrm{MOB}$, contained a very well-developed ICM system, while Methylocella palustris $\mathrm{K}^{\mathrm{T}}$ did not. This ICM system, which was observed in cells of strain $\mathrm{B}^{\mathrm{T}}$ under all growth conditions, appeared as stacks of membrane vesicles packed in parallel on only one side of the cell membrane. This pattern of ICM arrangement is different from the ICM of both type I and type II methanotrophs. To confirm the observations obtained with ultrathin sections, cell structure studies were also performed by the freeze-fracture method, which prevents any mechanical damage to cell structures and provides the most native pictures of ICM arrangements. The freeze-fracture images clearly showed the difference between the ICM arrangement in cells of strain $\mathrm{B} 2^{\mathrm{T}}$ and those in known types of methanotrophs. The membranes of strain $\mathrm{B} 2^{\mathrm{T}}$ were also aligned parallel to the cell wall (similar to type II ICM), but they were always located on only one side of the cell membrane and never formed uninterrupted vesicles, while they were also closely packed in stacks like ICM of type I methanotrophs. We suggest this membrane pattern as a type III of ICM arrangement in methanotrophic bacteria.

The two acidophilic methanotrophs, Methylocella palustris and strain $\mathrm{B} 2^{\mathrm{T}}$, were obtained using different enrichment and isolation procedures. The Methylo- cella-specific isolation approach included enrichment on nitrogen-sufficient liquid medium followed by agar surface plating, while strain $\mathrm{B}^{\mathrm{T}}$ was enriched on nitrogen-free medium and isolated by serial dilution, as it did not form colonies on agar media. These two isolation strategies resulted in the selection of two micro-organisms with different growth characteristics. Although Methylocella palustris $\mathrm{K}^{\mathrm{T}}$ was capable of dinitrogen fixation, growth on nitrogen-free medium was poor and occurred only under microaerobic conditions. In contrast, strain $\mathrm{B} 2^{\mathrm{T}}$ grew very well on nitrogen-free medium under both aerobic and microaerobic conditions. This could be due to the protective effect of the polysaccharide matrix covering cell conglomerates of strain $\mathrm{B} 2^{\mathrm{T}}$.

The metabolic pattern of strain $\mathrm{B} 2^{\mathrm{T}}$ was more similar to that of Methylocella than to those of Methylocystis and Methylosinus. However, only NADH-specific hydroxypyruvate reductase activity was detected in cell extracts of strain $\mathrm{B} 2^{\mathrm{T}}$, while all three strains of Methylocella palustris showed both NADH- and NADPH-specific activities. Enzyme activities related to the pentose phosphate cycle were found in strain $\mathrm{B} 2^{\mathrm{T}}$, while such activities were not detected in members of the Methylocystis/Methylosinus group.

Like all members of the Methylosinus/Methylocystis group, the two acidophilic methanotrophs contained 18:1 fatty acids as the predominant PLFAs. However, the predominant PLFA in strain $\mathrm{B} 2^{\mathrm{T}}$ and Methylocella palustris $\mathrm{K}^{\mathrm{T}}$ was $18: 1 \omega 7 c$, while $18: 1 \omega 8 c$, characteristic of the Methylocystis/Methylosinus group, was not detected. Previously, 18:1 $108 \mathrm{c}$ PLFA was considered highly indicative of type II methanotrophs and thus widely used as a signature fatty acid in environmental studies on MOB. Our data show that the applicability of this marker is restricted to members of the genera Methylocystis and Methylosinus and, consequently, should not be considered universal for all type II MOB.

In contrast to all previously known methanotrophs, we also found 17-carbon PLFAs in detectable amounts (up to $1 \%$ ) in the acidophilic strains, i.e. i17:0 and 17: $1 \omega 7 c$ in strain B2 ${ }^{\mathrm{T}}$ and 17:0 and 17:1 $1 \omega 8 \mathrm{c}$ in Methylocella palustris $\mathrm{K}^{\mathrm{T}}$. Interestingly, such 17-carbon PLFAs, as well as large amounts of $18: 1 \omega 7 c$, which may both be indicative of this novel type II subgroup of acidophilic methanotrophs, were found to be ${ }^{14} \mathrm{C}$ labelled in soil samples that showed atmospheric methane uptake after incubation with ${ }^{14} \mathrm{CH}_{4}$ (Holmes et al., 1999; Roslev \& Iversen, 1999). These ${ }^{14} \mathrm{CH}_{4^{-}}$ PLFA fingerprinting studies provide evidence for the presence of active methanotrophs in those soils that act as sinks for atmospheric methane and, by inference, provide some evidence for the wide ecological distribution of acidophilic methanotrophs and their probable contribution to the oxidation of atmospheric methane.

In contrast to the PLFA profiles, which were shown to be very similar for the two acidophilic methanotrophs, 
Methylocapsa acidiphila gen. nov., sp. nov.

Table 3. Major characteristics that distinguish Methylocapsa gen. nov. and other genera of type II methanotrophs

\begin{tabular}{|c|c|c|c|c|}
\hline Characteristic & Methylosinus & Methylocystis & Methylocella & Methylocapsa \\
\hline Cell morphology & Vibrioid or pyriform & $\begin{array}{l}\text { Coccobacillary or } \\
\text { curved rods }\end{array}$ & $\begin{array}{l}\text { Bipolar straight or curved } \\
\text { rods }\end{array}$ & Curved coccoids \\
\hline Motility & $+/-$ & - & - & - \\
\hline Rosette formation & + & - & - & - \\
\hline Type of resting cell & Exospores & Cysts & Exospores & Azotobacter-type cysts \\
\hline ICM arrangement & $\begin{array}{l}\text { Paired membranes } \\
\text { aligned to periphery } \\
\text { of cell (type II) }\end{array}$ & $\begin{array}{l}\text { Paired membranes } \\
\text { aligned to } \\
\text { periphery of cell } \\
\text { (type II) }\end{array}$ & $\begin{array}{l}\text { Vesicular membrane system } \\
\text { connected to the } \\
\text { cytoplasmic membrane }\end{array}$ & $\begin{array}{l}\text { Membrane vesicles } \\
\text { packed in parallel on } \\
\text { one side of the cell } \\
\text { membrane (type III) }\end{array}$ \\
\hline \multicolumn{5}{|l|}{ Growth at: } \\
\hline $30^{\circ} \mathrm{C}$ & + & + & - & + \\
\hline $\mathrm{pH} 5$ & - & - & + & + \\
\hline $0.5 \% \mathrm{NaCl}$ & + & + & - & - \\
\hline \multicolumn{5}{|l|}{ Activity of: } \\
\hline sMMO & $+/-$ & $+/-$ & + & - \\
\hline $\mathrm{pMMO}$ & + & + & - & + \\
\hline Pyruvate kinase & - & - & + & - \\
\hline Major phospholipids & Phosphatidylglycerol & Phosphatidylglycerol & Phosphatidylmethylethanolamine & Phosphatidylglycerol \\
\hline Major PLFAs & $18: 1 \omega 8 c$ & $18: 1 \omega 8 c$ & $18: 1 \omega 7 c$ & $18: 1 \omega 7 c$ \\
\hline $\begin{array}{l}\mathrm{G}+\mathrm{C} \text { content } \\
(\mathrm{mol} \%)\end{array}$ & $62-67$ & $62-67$ & 61 & 63 \\
\hline
\end{tabular}

the phospholipid analysis confirmed a profound difference between strain $\mathrm{B} 2^{\mathrm{T}}$ and Methylocella palustris $\mathrm{K}^{\mathrm{T}}$. Similar to Methylosinus, the major phospholipids in strain $\mathrm{B} 2^{\mathrm{T}}$ were represented by phosphatidylglycerols, while this type of phospholipid could not be detected in Methylocella palustris $\mathrm{K}^{\mathrm{T}}$. In contrast, $94 \%$ of total phospholipids in Methylocella palustris $\mathrm{K}^{\mathrm{T}}$ were phosphatidylmethylethanolamines, which were not found in Methylosinus and were present only at a very low level (about $3 \%$ ) in cells of strain $\mathrm{B} 2^{\mathrm{T}}$.

The 16S rRNA gene sequence similarity between strain $\mathrm{B} 2^{\mathrm{T}}$ and Methylocella palustris $\mathrm{K}^{\mathrm{T}}$ was $97 \cdot 3 \%$. Although this value often indicates members of the same genus, it is in the range of $16 \mathrm{~S}$ rDNA sequence similarities that separate members of the genera Methylosinus and Methylocystis. For instance, sequence similarities between $16 \mathrm{~S}$ rDNA of Methylocystis parvus $\mathrm{OBBP}^{\mathrm{T}}$, Methylosinus trichosporium $\mathrm{OB}^{\mathrm{T}} \mathrm{b}^{\mathrm{T}}$ and Methylosinus sporium are in the range 97.5-98\% (Dedysh et al., 2000). The profound genotypic distinctness between strain $\mathrm{B} 2^{\mathrm{T}}$ and Methylocella palustris $\mathrm{K}^{\mathrm{T}}$ was revealed by only $7 \%$ DNA-DNA hybridization, a value far below $70 \%$, which has been defined as the threshold for considering two strains as belonging to the same genospecies (Wayne et al., 1987). According to this criterion, strain $\mathrm{B} 2^{\mathrm{T}}$ would have to be considered at least a novel species. Moreover, the DNA-DNA hybridization value determined for strain $\mathrm{B} 2^{\mathrm{T}}$ and Methylocella palustris $\mathrm{K}^{\mathrm{T}}$ falls into the range of such values observed between members of different genera of type II MOB. Indeed, the values between the type species of the genera Methylosinus and Methylocystis range from 7 to $21 \%$ (Bowman et al., 1993).

Taking into consideration the obvious morphological, ultrastructural, biochemical and genotypic differences between strain $\mathrm{B} 2^{\mathrm{T}}$ and Methylocella palustris $\mathrm{K}^{\mathrm{T}}$, we believe that strain $\mathrm{B} 2^{\mathrm{T}}$, although phylogenetically related to Methylocella palustris $\mathrm{K}^{\mathrm{T}}$, should be considered a novel genus of serine pathway methanotroph. We propose the generic name Methylocapsa gen. nov., with the type species Methylocapsa acidiphila sp. nov. In this context, an additional, important feature for their differentiation into different genera is that strain $\mathrm{B} 2^{\mathrm{T}}$ and Methylocella palustris $\mathrm{K}^{\mathrm{T}}$, although inhabiting the same habitat (i.e. Sphagnum peat bogs), probably occupy different ecological niches. These acidophilic methanotrophs seem to express different types of MMO, i.e. sMMO by Methylocella palustris $\mathrm{K}^{\mathrm{T}}$ and $\mathrm{pMMO}$ by strain $\mathrm{B} 2^{\mathrm{T}}$. The characteristics that differentiate the genus Methylocapsa from the genus Methylocella as well as from other genera of the serinepathway methanotrophs are summarized in Table 3.

\section{Description of Methylocapsa gen. nov.}

Methylocapsa [Me.thy.lo.cap'sa. N.L. n. methyl the methyl group; L. n. capsa a cover or capsule (receptacle, container); N.L. fem. n. Methylocapsa methyl-using cell covered by a capsule].

Gram-negative, curved coccoids, $0.5-0.8 \mu \mathrm{m}$ wide by $0 \cdot 8-1 \cdot 2 \mu \mathrm{m}$ long. Cells occur singly or form roundshaped conglomerates surrounded by extracellular polysaccharide matrix; do not form rosettes. Repro- 
duce by binary fission. Non-motile. Produce intracellular PHB granules. Resting cells are Azotobactertype cysts. Cells are not lysed by $2 \%$ SDS. Cells possess a well-developed ICM system of type III which appears as stacks of membrane vesicles packed in parallel on only one side of the cell membrane. Does not express sMMO. The temperature range for growth is $10-30{ }^{\circ} \mathrm{C}$ with the optimum at $20-24^{\circ} \mathrm{C}$; no growth at $37^{\circ} \mathrm{C}$. Growth occurs between $\mathrm{pH} 4 \cdot 2$ and 7·2. Prefers dilute media of low salt content. Obligate utilizer of $\mathrm{C}_{1}$ compounds via the serine pathway. Does not contain the ribulose monophosphate and ribulose bisphosphate enzymes. Tricarboxylic acid cycle is complete. Capable of atmospheric nitrogen fixation. The major PLFA is $18: 1 \omega 7 c$ and the major phospholipids are phosphatidylglycerols. The $\mathrm{G}+\mathrm{C}$ content is $63 \mathrm{~mol} \%$. Belongs to the $\alpha$-subclass of the Proteobacteria; phylogenetically related to the acidophilic methanotrophic bacterium Methylocella palustris $\mathrm{K}^{\mathrm{T}}$ and the acidophilic heterotrophic bacterium Beijerinckia indica subsp. indica. The type and only species is Methylocapsa acidiphila. Habitat is acidic wetlands, particularly Sphagnum peat bogs.

\section{Description of Methylocapsa acidiphila gen. nov., sp. nov.}

Methylocapsa acidiphila (a.ci.di'phi.la. N.L. n. acidum acid from L. adj. acidus sour; Gr. adj. philus loving; N.L. fem. adj. acidiphila acid-loving).

Description as for the genus plus the following traits. Optimal growth at $20-24{ }^{\circ} \mathrm{C}$ and at $\mathrm{pH} 5 \cdot 0-5 \cdot 5$. Carbon sources used include methane and methanol. Methanol supports growth only when used at concentrations below $0.05 \%(\mathrm{v} / \mathrm{v}) . \mathrm{NaCl}$ inhibits growth at a concentration of $0.5 \%(\mathrm{w} / \mathrm{v})$.

The type strain is strain $\mathrm{B} 2^{\mathrm{T}}\left(=\mathrm{DSM} 13967^{\mathrm{T}}=\right.$ NCIMB $13765^{\mathrm{T}}$ ), which was isolated from Sphagnum-Carex peat of Bakchar bog, West Siberia $\left(56^{\circ} \mathrm{N}\right.$, $\left.82^{\circ} \mathrm{E}\right)$.

\section{ACKNOWLEDGEMENTS}

This research was supported in part by the Russian Fund of Basic Research (grants no. 99-04-48725 and 99-04-04035), the EC CONGAS Project and by the Deutsche Forschungsgemeinschaft (436 RUS 113/543/0). We also thank Jaisong Fang (University of Michigan) for assistance with intact phospholipid analysis.

\section{REFERENCES}

Bowman, J. P., Sly, L. I., Nichols, P. D. \& Hayward, A. C. (1993). Revised taxonomy of the methanotrophs: description of Methylobacter gen. nov., emendation of Methylococcus, validation of Methylosinus and Methylocystis species, and a proposal that the family Methylococcaceae includes only the group I methanotrophs. Int J Syst Bacteriol 43, 735-753.

Brusseau, G. A., Tsien, H. C., Hanson, R. S. \& Wackett, L. P. (1990). Optimization of trichloroethylene oxidation by methanotrophs and the use of a colorimetric assay to detect soluble methane monooxygenase activity. Biodegradation 1, 19-29.
Dedysh, S. N., Panikov, N. S. \& Tiedje, J. M. (1998a). Acidophilic methanotrophic communities from Sphagnum peat bogs. Appl Environ Microbiol 64, 922-929.

Dedysh, S. N., Panikov, N. S., Liesack, W., Großkopf, R., Zhou, J. \& Tiedje, J. M. (1998b). Isolation of acidophilic methane-oxidizing bacteria from northern peat wetlands. Science 282, 281-284.

Dedysh, S. N., Liesack, W., Khmelenina, V. N., Suzina, N. E., Trotsenko, Y. A., Semrau, J. D., Bares, A. M., Panikov, N. S. \& Tiedje, J. M. (2000). Methylocella palustris gen. nov., sp. nov., a new methane-oxidizing acidophilic bacterium from peat bogs, representing a novel subtype of serine-pathway methanotrophs. Int J Syst Evol Microbiol 50, 955-969.

Dunlop, W. F. \& Robards, A. W. (1973). Ultrastructural study of poly- $\beta$-hydroxybutyrate granules from Bacillus cereus. $J$ Bacteriol 114, 1271-1280.

Fang, J., Barcelona, M. J. \& Semrau, J. D. (2000). Characterization of methanotrophic bacteria on the basis of intact phospholipid profiles. FEMS Microbiol Lett 189, 67-72.

Gerhardt, P. (editor) (1981). Manual of Methods for General Bacteriology. Washington, DC: American Society for Microbiology.

Guckert, J. B., Ringelberg, D. B., White, D. C., Hanson, R. S. \& Bratina, B. J. (1991). Membrane fatty acids as phenotypic markers in the polyphasic taxonomy of methylotrophs within the Proteobacteria. J Gen Microbiol 137, 2631-2641.

Holmes, A. J., Roslev, P., McDonald, I. R., Iversen, N., Henriksen, K. \& Murrell, J. C. (1999). Characterization of methanotrophic bacterial populations in soils showing atmospheric methane uptake. Appl Environ Microbiol 65, 3312-3318.

Jukes, T. H. \& Cantor, C. R. (1969). Evolution of protein molecules. In Mammalian Protein Metabolism, vol. 3, pp. 21-132. Edited by H. N. Munro. New York: Academic Press.

Khmelenina, V. N., Kalyuzhnaya, M. G., Starostina, N. G., Suzina, N. E. \& Trotsenko, Y. A. (1997). Isolation and characterization of halotolerant alkaliphilic methanotrophic bacteria from Tuva soda lakes. Curr Microbiol 35, 257-261.

Khmelenina, V. N., Kalyuzhnaya, M. G., Sakharovsky, V. G., Suzina, N. E., Trotsenko, Y. A. \& Gottschalk, G. (1999). Osmoadaptation in halophilic and alkaliphilic methanotrophs. Arch Microbiol 172, 321-329.

Lontoh, S. \& Semrau, J. D. (1998). Methane and trichloroethylene degradation by Methylosinus trichosporium OB3b expressing particulate methane monooxygenase. Appl Environ Microbiol 64, 1106-1114.

Luft, J. H. (1964). Electron microscopy of cell extraneous coats as revealed by ruthenium red staining. $J$ Cell Biol 23, $54 \mathrm{~A}-55 \mathrm{~A}$.

Lysenko, A. M., Gal'chenko, V. F. \& Chernykh, N. A. (1988). Taxonomic study of obligate methanotrophic bacteria using the DNA-DNA hybridization technique. Microbiology (English translation of Mikrobiologiya) 57, 653-658.

Owen, R. J., Lapage, S. P. \& Hill, L. R. (1969). Determination of base composition from melting profiles in dilute buffers. Biopolymers 7, 503-516.

Roslev, P. \& Iversen, N. (1999). Radioactive fingerprinting of microorganisms that oxidize atmospheric methane in different soils. Appl Environ Microbiol 65, 4064-4070.

Saitou, N. \& Nei, M. (1987). The neighbor-joining method: a new method for reconstructing phylogenetic trees. Mol Biol Evol 4, 406-425.

Socolofsky, M. D. \& Wyss, O. (1961). Cysts of Azotobacter. J Bacteriol 81, 946-954. 
Suzina, N. E., Duda, V. I., Anisimova, L. A., Dmitriev, V. V. \& Boronin, A. M. (1995). Cytological aspects of resistance to potassium tellurite conferred on Pseudomonas cells by plasmids. Arch Microbiol 163, 282-285.

Takeda, K. (1988). Characteristics of a nitrogen-fixing methanotroph, Methylocystis T-1. Antonie Leeuwenhoek 54, 521-534.

Wayne, L. G., Brenner, D. J., Colwell, R. R. \& 9 other authors

(1987). Report of the ad hoc committee on reconciliation of approaches to bacterial systematics. Int J Syst Bacteriol 37, 463-464.

Whittenbury, R., Phillips, K. C. \& Wilkinson, J. F. (1970a). Enrichment, isolation and some properties of methane-utilizing bacteria. J Gen Microbiol 61, 205-218.

Whittenbury, R., Davies, S. L. \& Davey, J. F. (1970b). Exospores and cysts formed by methane-utilizing bacteria. J Gen Microbiol 61, 219-226. 